\title{
KAJIAN SISTEM ALIRAN PADA DAERAH ALIRAN SUNGAI (DAS) BENDUNG KOTA PALEMBANG
}

\author{
Muhammad Caisar Arfy ${ }^{1)}$, Ishak Yunus ${ }^{2)}$, Mudiono Kasmuri ${ }^{3)}$ \\ Mahasiswa Universitas Bina Darma Palembang ${ }^{1)}$ e-mail : caisar_arfy@yahoo.co.id \\ Dosen Universitas Bina Darma Palembang ${ }^{2)}$ e-mail : ishak_yunus@binadarma.ac.id \\ Dosen Universitas Bina Darma Palembang ${ }^{3)}$ e-mail : mudionokasmuri@yahoo.com
}

\begin{abstract}
ABSTRAK
Sungai bendung adalahsalahsatudari 9 anaksungaimusi yang beradadikotaPalembang.Muarasungaiiniterletak di jalanSlametRiyadi 10 Ilir, kecamatan Ilir Tim. II, Kota Palembang. Sungai ini dipengaruhi siklustahunanmusimpenghujanpadabulan September sampaibulanapril. Sungai Bendung memiliki luas DAS $15,4 \mathrm{~km}^{2}$ dan merupakansalahsatusungai di Kota Palembang yang seringmengalamilimpasanakibatbanjir. Dalamanalisa yang dilakukan di Daerah Aliran Sungai BendungKuto Palembang, diperolehnilai debit hujanrencanauntuk kala ulang 10 tahunyaitu1,683 m³/detdan debiteksistingterbesar 2,330 untuksaluran $\mathrm{S} 1$ dan $\mathrm{S} 2,1,432$ $\mathrm{m}^{3} /$ detuntuksaluran S3 dan S4. Jadi berdasarkan dari perhitungan tersebut maka dapat disimpulkan bahwa saluran saluran yang tidak memenuhi atau tidak mampu menampung debit hujan maka perlu adanya kajian yang lebih lanjut sehingga akan mendapatkan solusi atau jalan keluar yang tepatbaik diperbesar dimensi atau hanya diperbaiki.
\end{abstract}

Kata kunci :hujan, limpasan, drainase

\begin{abstract}
Bendung River is one of the nine Musi River's streams located in Palembang. Its estuary is located on Jalan SlametRiyadi 10 ilir, Ilir Timur II Palembang. This river is affected by the annual cycle of the rainy season on September until April. The width of the drainage area of this Bendung river $15,4 \mathrm{~km}^{2}$ and it is one of the rivers where flood often occurs. Based on the analysis which was done in the area of Kuto Bendung river in Palembang, the velue of the planning rain debit for ten years was $1,683 \mathrm{~m}^{3} / \mathrm{sec}$ and the largest existing debit was $2,330 \mathrm{~m}^{3} / \mathrm{sec}$ for $S 1$ and $S 2$ waterways, and $1,432 \mathrm{~m}^{3} / \mathrm{sec}$ for $\mathrm{S} 3$ and $\mathrm{S} 4$ waterways. Thus, there should be further studies to solve the problem well or the correct way by making the dimension becomes larger or fixing it.
\end{abstract}

Keywords :rain, runoff, drainage

\section{PENDAHULUAN}

Sungai bendung adalah salahsatu dari 9 anak sungai musi yang berada di Kota Palembang. Muara sungai ini terletak di jalan Slamet Riyadi 10 Ilir, kecamatan Ilir Timur II, Kota Palembang. Sungai ini dipengaruhi siklus tahunan musim penghujan pada bulan September sampai bulan april. Berdasarkan data dari Daftar Laporan Interim Balai Besar Wilayah Sungai Sumatera VIII Sungai Bendung memiliki luas DAS $15,4 \mathrm{~km}^{2}$ dan
Merupakan salah satu sungai di Kota Palembang yang sering mengalami limpasan akibat banjir.

Panjang utama Sungai Bendung adalah $5,5 \mathrm{~km}$ dengan dimensi lebar $15 \mathrm{~m}$, dengan kedalaman muka air sungai bervariasi dari 2,0 m sampai 3,0 m. DAS Bendung terdiri dari $75 \%$ permukiman penduduk, $20 \%$ perdagangan/jasa dan perkantoran, dan $5 \%$ adalah rawa perlindungan. Sungai ini juga 
berfungsi sebagai pengendali banjir di kota palembang.

Berdasarkan permasalahan diatas, maka dapat dirumuskan masalah yang akan yaitu bagaimana kemampuan daya tamping aliran tersier terhadap curah hujan yang tinggi, dan bagaimana pengaruh pasang surut yang terjadi di Daerah Aliran Sungai (DAS) Bendung Kuto.

Batasan yang diberikan ialah Menghitung perkiraan debit aliran sungai bendung Kuto Palembang, Mengukur dimensi saluran sungai Bendung Kuto Palembang, Menganalisa sistem aliran Daerah Aliran Sungai (DAS).

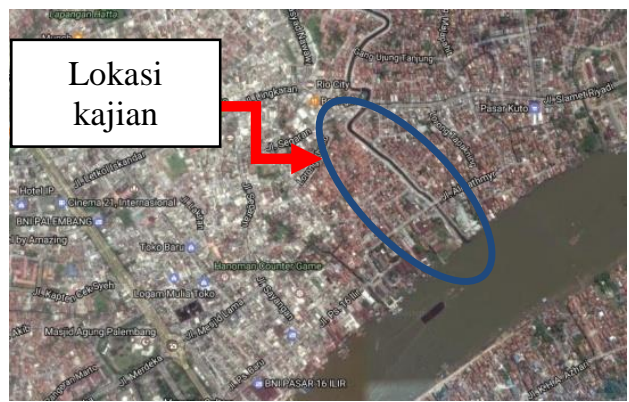

Gambar 1 : Lokasi Kajian

(Sumber : www.googlemaps.com)

\section{TINJAUAN PUSTAKA}

\section{Analisa Frekuensi Curah Hujan}

Sistem hidrologi kadang-kadang dipengaruhi oleh peristiwa-peristiwa yang luar biasa (ekstrim), seperti hujan lebat, banjir, dan kekeringan. Besaran peristiwa ekstrim berbanding terbalik dengan frekuensi kejadiannya, peristiwa yang luar biasa ekstrim kejadiannya sangat langka.

Analisis frekuensi merupakan prakiraan, dalam arti probabilitas untuk terjadinya suatu peristiwa hidrologi dalam bentuk hujan rencana yang berfungsi sebagai dasar perhitungan perencanaan hidrologi untuk antisipasi setiap kemungkinan yang akan terjadi.

Tujuan analisis frekuensi data hidrologi adalah berkaitan dengan besaran peristiwa-peristiwa ekstrim yang berkaitan dengan frekuensi kejadiannya melalui distribusi kemungkinan. Data hidrologi yang dianalisis diasumsikan tidak bergantung dan terdistribusi secara acak dan bersifat stokastik.

\section{a. Distribusi Normal}

Dalam analisis hidrologi distribusi normal sering digunakan untuk menganalisis frekuensi curah hujan, analisis statsistik dari distribusi curah hujan tahunan, debit rata-rata tahunan. Rumus yang digunakan dalam perhitungan: $\mathrm{X}_{\mathrm{T}}=\bar{X}+\mathrm{K}_{\mathrm{T}} \mathrm{Sx}$

Dimana :

$\mathrm{X}_{\mathrm{T}}=$ curah hujan rencana dengan periode ulang $\mathrm{T}$

$\bar{X}=$ curah hujan maksimum rata-rata

$\mathrm{K}_{\mathrm{T}}=$ faktor frekuensi, nilainya bergantung dari T (tabel 2.1)

$\mathrm{Sx}=$ Standar deviasi $\sqrt{\frac{1}{1-n} \sum\left(\mathrm{X}_{1}-\bar{X}\right)^{2}}$

\section{b. Log Normal}

Distribusi Log Normal, merupakan hasil tranformasi dari distribusi normal, yaitu dengan mengubah varian $X$ menjadi nilai logaritmik varian $\mathrm{X}$.

Rumus yang digunakan adalah sebagai berikut:

$\log \mathrm{X}_{\mathrm{T}}=\log \underline{\bar{X}}+\mathrm{K}_{\mathrm{T}} \cdot \mathrm{S} \log \mathrm{X}$

Dimana :

$\mathrm{Xt}=$ Nilai logaritmis curah hujan rencana dengan periode ulang $\mathrm{T}$.

Sx $=$ Standar deviasi dari

$\log \mathrm{X}=\sqrt{\frac{1}{1-n} \sum\left(\log \mathrm{X}_{1}-\overline{\log X}\right)^{2}}$

$\bar{X}=$ Curah hujan rata-rata dari $\log \bar{X}$

$\mathrm{Kt}=$ Faktor frekuensi, nilainya bergantung dari T (tabel 2.1)

Distribusi tipe Log Normal, mempunyai koefisien kemencengan (Coefficient of skewness)

$\mathrm{Cs}=3 \mathrm{Cv}+\mathrm{Cv}^{3}$. Syarat lain distribusi sebaran Log Normal $\mathrm{C}_{\mathrm{k}}=\mathrm{Cv}^{8}+6 \mathrm{Cv}^{6}+$ $15 \mathrm{Cv}^{4}+16 \mathrm{Cv}^{2}+3$.

\section{c. Distribusi Gumbel}

Umumnya digunakan untuk analisis data maksimum, misalnya analisis frekuensi banjir. Rumus yang digunakan dalam perhitungan adalah sebagai berikut: $\mathrm{Xt}=\underline{\bar{X}}+\frac{\left(\mathrm{Y}_{\mathrm{t}}-\mathrm{Y}_{\mathrm{n}}\right)}{\sigma_{\mathrm{n}}} \times \mathrm{S}$.

Dimana :

$\mathrm{Xt}=$ Curah hujan rencana dalam periode 


\author{
ulang $\mathrm{T}$ tahun (mm) \\ $\bar{X}=$ Curah hujan rata-rata hasil \\ pengamatan ( $\mathrm{mm})$ \\ $\mathrm{Yt}=$ Recuded variabel, parameter gumbel \\ untuk periode $\mathrm{T}$ tahun \\ Yn = Recuded mean, merupakan fungsi \\ dari banyaknya data. \\ $\mathrm{Sn}=$ Recuded standar deviasi, \\ merupakan fungsi dari banyaknya data \\ (n).
}

\section{d. Distribusi Log Pearson Type III}

Distribusi log pearson type III digunakan untuk analisis variabel hidrologi dengan varian minimun misalnya, analisis frekuensi distribusi dari debit minimum (low flow).

Langkah-langkah perhitungannya adalah sebagai berikut:

Mengubah data curah hujan sebanyak $n$ buah $X_{1}, X_{2}, X_{3}, \ldots . . X_{n}$ menjadi $\log \left(X_{1}\right)$, $\log \left(X_{2}\right), \log \left(X_{3}\right), \ldots \ldots . . \log \left(X_{n}\right)$.

Menghitung harga rata-ratanya dengan rumus:

$$
\overline{\log X}=\frac{1}{n} \sum_{i=l}^{n} \log \mathrm{X} i
$$

Dimana :

$\underline{\underline{\log X}}=$ harga rata-ratalogaritmik

$\mathrm{N} \quad=$ jumlah data

$\mathrm{Xi}=$ nilai curah hujan tiap -

tiap tahun $\left(\mathrm{R}_{24}\right.$ maks).

Menghitung harga standar deviasinya dengan rumus berikut:

$S d=\sqrt{\frac{1}{n-1} \sum_{i=l}^{n}(\log \mathrm{X} i-\overline{\log X})^{2}}$

Menghitung koefisien skewness (Cs) dengan rumus:

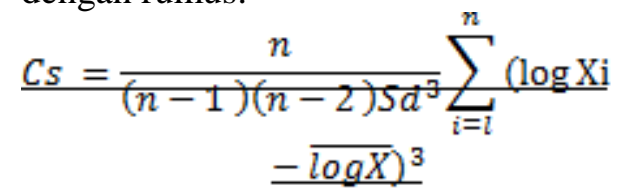

Menghitung logaritma hujan rencana dengan periode ulang $\mathrm{T}$ tahun dengan rumus:

$$
\log (\mathrm{Xt})=\overline{\log X}+\mathrm{K} \cdot \mathrm{Sd}
$$

Dimana :

$\log (\mathrm{Xt})=$ Logaritma curah hujan dalam periode ulang $\mathrm{T}$ tahun $(\mathrm{mm})$.

$\overline{\log X}=$ Rata-rata $\log \mathrm{X}$

$\mathrm{K}=$ Faktor frekuensisebaran log pearson type III(tabel)

$\mathrm{n} \quad=$ Jumlah pengamatan

Cs = Koefisien kemencengan

Menghitung koefisien kurtosis (Ck) dengan rumus :

$\mathrm{Ck}=\frac{\sum\{\log (\mathrm{Xi})-\overline{\log (\mathrm{X})}\}^{4}}{(\mathrm{n}-1)(\mathrm{n}-2)(\mathrm{n}-3) S d^{4}}$

Menghitung koefisien variasi (Cv) dengan rumus :

$$
C v=\frac{S d}{\log (x]} .
$$

Distribusi Log Pearson Tipe III, mempunyai koefisien kemencengan (Coefficient of skewness) atau $\mathrm{Cs} \neq 0$.

$\mathrm{Sx}=$ Standar deviasi

$$
=\frac{1}{\sqrt{1-n} \sum_{v}\left(\mathrm{X}_{1}-\bar{X}\right)^{2}}
$$

\section{Intensitas Hujan}

Intensitas hujan adalah jumlah hujan yang dinyatakan dalam tinggi hujan atau volume hujan tiap satuan waktu.Besarnya intensitas hujan berbeda-beda, tergantung dari lamanya curah hujan dan frekuensi kejadiannya. Intensitas hujan diperoleh dengan cara melakukan analisis data hujan baik secara statistik maupun secara empiris. Intensitas hujan ialah ketinggian hujan yang terjadi pada suatu kurun waktu air hujan terkonsentrasi (Wesli, 2008).

Intensitas hujan biasanya dihubungkan dengan durasi hujan jangka pendek misalnya 5 menit, 30 menit, 60 menit dan berjam-jam. Apabila yang tersedia hanya data hujan harian ini, maka intensitas hujan dapat diestimasi dengan menggunakan rumus Mononobe seperti berikut :

$$
\mathrm{I}=\frac{R_{24}}{24}\left(\frac{24}{\tau}\right)^{2 / 3}
$$

Keterangan :

$\mathrm{I}=$ Intensitas curahhujan( $\mathrm{mm} / \mathrm{jam})$

R24 =Curah hujan maksimum dalam 24 jam $(\mathrm{mm})$. 
$\mathrm{t}=$ Durasi (lamanya) curah hujan (menit) atau (jam).

\section{Koefisien Pengaliran}

Koefisien pengaliran (run-off coefficient) adalah perbandingan antara jumlah air hujan yang mengalir atau melimpas di atas permukaan tanah (surface run-off) dengan jumlah air hujan yang jatuh dari atmosfer. Nilai koefisien pengaliran berkisar antara 0 sampai dengan 1 dan bergantung dari jenis tanah, jenis vegetasi, karakteristik tata guna lahan dan konstruksi yang ada di permukaan tanah seperti jalan aspal, atap bangunan dan lain-lain, yang menyebabkan air hujan tidak dapat sampai secara langsung ke permukaan tanah sehingga tidak dapat berinfiltrasi, maka akan menghasilkan limpasan permukaan hampir $100 \%$. Koefisien pengaliran dapat ditentukan berdasarkan curah hujan (Wesli, 2008).

Adapun rumus untuk menentukan koefisien pengaliran adalah sebagai berikut<smiles>[CH]=[V]</smiles>

Keterangan :

$\mathrm{C}=$ Koefisien limpasan

$\mathrm{Q}=$ Jumlah limpasan

$\mathrm{R}=$ Jumlah curah hujan

Besarnya nilai koefisien pengaliran $(\mathrm{C})$ untuk daerah perumahan berdasarkan penelitian para ahli dapat dilihat pada Tabel berikut ini :

\begin{tabular}{|c|l|c|}
\hline No & \multicolumn{1}{|c|}{ Kondisi Permukaan Tanah } & C \\
\hline 1 & Jalan beton dan jalan aspal & $0,70-0,95$ \\
\hline 2 & Jalan kerikil dan jalan tanah & $0,40-0,70$ \\
\hline 3 & $\begin{array}{l}\text { Bahu jalan dari tanah berbutir } \\
\text { halus }\end{array}$ & $0,40-0,55$ \\
\hline 4 & $\begin{array}{l}\text { Bahu jalan dari tanah berbutir } \\
\text { kasar }\end{array}$ & $0,10-0,20$ \\
\hline 5 & $\begin{array}{l}\text { Bahu jalan dari batuan masih } \\
\text { keras }\end{array}$ & $0,70-0,85$ \\
\hline 6 & $\begin{array}{l}\text { Bahu jalan dari batuan masih } \\
\text { lunak }\end{array}$ & $0,60-0,75$ \\
\hline 7 & Daerah perkotaan & $0,70-0,95$ \\
\hline 8 & Daerah pinggiran kota & $0,60-0,70$ \\
\hline 9 & Daerah industry & $0,60-0,90$ \\
\hline 10 & Pemukiman padat & $0,40-0,60$ \\
\hline
\end{tabular}

\begin{tabular}{|c|l|c|}
\hline 11 & Pemukiman tidak padat & $0,40-0,60$ \\
\hline 12 & Taman dan kebun & $0,45-0,60$ \\
\hline 13 & Persawahan & $0,70-0,80$ \\
\hline 14 & Perbukitan & $0,70-0,80$ \\
\hline 15 & Pegunungan & $0,75-0,90$ \\
\hline 15 & Pegunungan & $0,75-0,90$ \\
\hline
\end{tabular}

(Sumber :Tata cara perencanaan drainase permukaan jalan, SNI 03-3424-1994)

\section{Waktu Konsentrasi}

Waktu konsentrasi adalah waktu yang diperlukan untuk mengalirkan air hujan dari titik terjauh menuju suatu titik tertentu ditinjau pada derah pengaliran. Umumnya waktu konsentrasi teridiri dari waktu yang diperlukan oleh air untuk mengalir pada permukaan tanah menuju saluran terdekat $\left(\mathrm{t}_{\mathrm{o}}\right)$ dan waktu untuk mengalir dalam saluran ke suatu tempat yang ditinjau $\left(t_{d}\right)$.

$$
\mathrm{t}_{\mathrm{c}}=\mathrm{t}_{\mathrm{o}}+\mathrm{t}_{\mathrm{d}}
$$

keterangan :

$t_{c}=$ waktu konsentrasi

$\mathrm{t}_{\mathrm{o}}=$ waktu yang dibutuhkan oleh air menuju saluran terdekat

$t_{d}=$ waktu untuk mengalir dalam saluran ke tempat yang di tinjau.

Untuk $t_{o}$ dan $t_{d}$ dapat dicari menggunakan rumus :

$$
\begin{aligned}
& t_{o}=\left(\frac{2}{3} \times 3,28 \times \operatorname{LoX} \frac{\text { nd }}{\sqrt{2}}\right)^{0,167} \\
& t_{d}=L / 60 V
\end{aligned}
$$

keterangan :

$\mathrm{t}_{\mathrm{o}}=$ waktu inlet (menit)

$\mathrm{t}_{\mathrm{d}}=$ waktu aliran dalam saluran (menit)

$\mathrm{L}_{\mathrm{o}}=\mathrm{Jarak}$ titik terjauh ke fasilitas drainase (meter)

$\mathrm{L}=$ Panjang saluran (meter)

Kajian Sistem Aliran Pada Daerah Aliran Sungai (DAS) Bendung Kota Palembang 
nd $=$ Koefisien hambatan (tabel 2.6)

$\mathrm{S}=$ Kemiringan daerah pengaliran /kemiringan tanah

$\mathrm{V}=$ Kecepatan rata-rata aliran dalam saluran.

\section{Debit Air Buangan}

Besarnya debit air buangan yang dihasilkan dari pola pemanfaatan lahan suatu kawasan ditentukan berdasarkan tingkat kepadatan penduduk yang ada (orang $/ \mathrm{m}$ ) serta didukung dengan data tentang fasilitas - fasilitas yang ada pada area tersebut. Perencanaan debit air buangan dihitung berdasarkan metode pendekatan jumlah aliran buangan yang dihitung berdasarkan tabel di bawah ini.

\begin{tabular}{|c|c|c|}
\hline No & Tipe & $\begin{array}{c}\text { Liter/org/ } \\
\text { hari }\end{array}$ \\
\hline 1 & Rumah Mewah & 150 \\
\hline 2 & Rumah Biasa & 120 \\
\hline 3 & Apartment & 150 \\
\hline 4 & Rumah Susun & 80 \\
\hline 5 & Asrama & 96 \\
\hline 6 & Klinik/puskesmas & 2,7 \\
\hline 7 & Rumah Sakit Mewah & 800 \\
\hline 8 & Rumah Sakit Menengah & 600 \\
\hline 9 & Rumah Sakit Umum & 340 \\
\hline 10 & SD & 32 \\
\hline 11 & SMP & 40 \\
\hline 12 & SMA & 64 \\
\hline 13 & Perguruan tinggi & 64 \\
\hline 14 & Rumah toko/ Rumah Kantor & 80 \\
\hline 15 & Pabrik & 40 \\
\hline 16 & Stasiun / Terminal & 2,7 \\
\hline 17 & Bandara Udara & 2,7 \\
\hline 18 & Restoran & 13,5 \\
\hline 19 & Gedung Pertunjukan & 9 \\
\hline 20 & Gedung Bioskop & 9 \\
\hline 21 & Hotel Melati s/d Bintang 2 & 120 \\
\hline 22 & Hotel Bintang 3 ke atas & 150 \\
\hline 23 & Gedung Peribadatan & 4,5 \\
\hline 24 & Perpustakaan & 22,5 \\
\hline 25 & Bar & 24 \\
\hline 26 & Perkumpulan Sosial & 27 \\
\hline
\end{tabular}

\begin{tabular}{|c|l|c|}
\hline 27 & Klab Malam & 188 \\
\hline 28 & Gedung Pertemuan & 20 \\
\hline 29 & Laboratorium & 120 \\
\hline
\end{tabular}

(Sumber: Wicaksono, 2000)

\section{Dimensi Saluran}

Dimensi saluran harus mampu mengalirkan debit rencana atau dengan kata lain debit yang dialirkan oleh saluran (Qs) sama atau lebih besar dari debit rencana (QT). Hubungan ini ditunjukkan sebagai berikut :

Qs $\geq$ QT

Debit suatu penampang saluran (Qs) dapat diperoleh denganmenggunakan rumus seperti di bawah ini :

$\mathrm{Qs}=\mathrm{As} \cdot \mathrm{V}$

Keterangan :

Qs = Debit penampang saluran (m3/det)

$\mathrm{As}=$ Luas penampang saluran tegak lurus arah aliran (m2)

$\mathrm{V}=$ Kecepatan rata-rata aliran di dalam saluran (m/det).

Kecepatan rata-rata aliran di dalam suatu saluran dapat dihitung dengan menggunakan rumus Manning seperti di bawah ini, yaitu :

$\mathrm{V}=\frac{1}{\bar{n}} \cdot \mathrm{R}^{2 / 3} \cdot \mathrm{S}_{1}{ }^{1 / 2}$
$\mathrm{R}=\frac{\mathrm{As}}{\mathrm{p}}$

Keterangan :

$\mathrm{V}=$ Kecepatan rata-rata alirandidalam saluran $(\mathrm{m} / \mathrm{det})$

$\mathrm{n}=$ Koefisien kekasaran Manning

$\mathrm{R}=$ Jari-jari hidrolis $(\mathrm{m})$

$\mathrm{S} 1=$ Kemiringan saluran

As $=$ Luas penampang saluran tegak lurus arah aliran (m2)

$\mathrm{P}=$ Keliling basah saluran $(\mathrm{m})$

\begin{tabular}{|l|l|l|}
\hline No & \multicolumn{1}{|c|}{ TipeSaluran } & \multicolumn{1}{c|}{$\begin{array}{c}\text { Koefisien } \\
\text { Manning (n) }\end{array}$} \\
\hline 1 & Baja & $0.011-0.014$ \\
\hline 2 & $\begin{array}{l}\text { Baja Permukaan } \\
\text { Gelombang }\end{array}$ & $0.021-0.030$ \\
\hline 3 & Semen & $0.010-0.013$ \\
\hline 4 & Beton & $0.011-0.015$ \\
\hline
\end{tabular}




\begin{tabular}{|l|l|l|}
\hline 5 & Pasangan Batu & $0.017-0.030$ \\
\hline 6 & Kayu & $0.010-0.014$ \\
\hline 7 & Bata & $0.011-0.015$ \\
\hline 8 & Aspal & 0.013 \\
\hline
\end{tabular}

Sumber : Drainase perkotaan (Wesli,2008).

Pada daerah-daerah yang telah diidentifikasi dan bermasalah, dilakukan perhitungan debit saluran drainase yang sudah ada (eksisting) dengan menggunakan persamaan Manning (Hardjosuprapto, 1998) dengan asumsi aliran mengalir penuh di saluran terbuka.Debit adalah luas penampang basah dikalikan dengan jari-jari hidrolis dipangkatkan dengan 2/3 dikalikan dengan akar kuadrat dari kemiringan saluran dibagi dengan koefisien kekasaran Manning.

$\mathrm{Q}=\mathrm{A} \cdot 1 \mathrm{n} \cdot \mathrm{R} 2 / 3 \cdot \mathrm{S} 1 / 2$

Keterangan :

$\mathrm{Q}=$ Debit saluran (m3/det)

$\mathrm{A}=$ Luas penampang basah $(\mathrm{m} 2)$

$\mathrm{n}=$ Koefisien kekasaran Manning

$\mathrm{R}=$ Jari-jari hidrolis $(\mathrm{m})$

$\mathrm{S}=$ Kemiringan saluran

Lalu hasil tersebut dibandingkan dengan perhitungan debit limpasan berdasarkan intensitas hujan yang diperoleh dari analisis hidrologi dengan menggunakan persamaan ModifikasiRasional (Hardjosuprapto, 1998). Debit adalah faktor konversi dikalikan dengan koefisien tampungan dikalikan dengan koefisien limpasan dikalikan dengan luas daerah pengaliran sungai.

\begin{tabular}{|c|l|c|}
\hline No & \multicolumn{1}{|c|}{ Jenis bahan } & $\mathrm{V}_{\text {izin }}(\mathrm{m} / \mathrm{det})$ \\
\hline 1 & Pasir halus & 0,45 \\
\hline 2 & Lempung kepasiran & 0,5 \\
\hline 3 & Lahan alluvial & 0,6 \\
\hline 4 & Kerikil halus & 0,75 \\
\hline 5 & Lempung keras/kokoh & 0,75 \\
\hline 6 & Lempung padat & 1,1 \\
\hline 7 & Kerikil kasar & 1,2 \\
\hline 8 & Batu-batu besar & 1,5 \\
\hline 9 & Beton-beton bertulang & 1,5 \\
\hline
\end{tabular}

(Sumber : H.M Halim Hasmar, 2011)
Lapisan dasar saluran dan dindingnya terbuat dari beton, pasangan batu kali, pasangan batu bata, aspal, kayu, besi cor, baja plastik atau dari tanah saja.

Kemiringan Dinding Saluran Berdasarkan Bahan Saluran

\begin{tabular}{|c|c|}
\hline \multirow{2}{*}{ Jenis material } & Kemiringan saluran \\
\cline { 2 - 2 } & $\mathrm{S}(\%)$ \\
\hline Tanah asli & $0-5$ \\
\hline Kerikil & $5-7,5$ \\
\hline Pasangan & 7,5 \\
\hline
\end{tabular}

(Sumber : H.M Halim Hasmar, 2011)

Kemiringan saluran adalah kemiringan dasar saluran dan kemiringan dinding saluran. Kemiringan dasar saluran maksimum yang diizinkan adalah 0,005-0,0075, tergantung pada bahan yang digunakan. Sedangkan kemiringan dasar minimum yang diperbolehkan adalah 0,001 kemiringan yang lebih curam dari 0,005 untuk tanah padat kan menyebabkan erosi (penggerusan).

Kecepatan minimum yang diizinkan adalah kecepatan terkecil yang tidak menimbulkan pengendapan dan tidak merangsang tumbuhnya tanaman aquatic dan lumut.

Kemiringan Saluran Berdasarkan Debit

\begin{tabular}{|c|c|}
\hline $\begin{array}{c}\text { Debit air } \mathrm{Q} \\
\left(\mathrm{m}^{3} / \mathrm{det}\right)\end{array}$ & $\begin{array}{c}\text { Kemiringan } \\
\text { saluran }\end{array}$ \\
\hline $0,00-0,75$ & $1: 1$ \\
\hline $0,75-15$ & $1: 1,5$ \\
\hline $15-80$ & $1: 2$ \\
\hline
\end{tabular}

(Sumber : Tata cara perencanaan drainase permukaan jalan, SNI 03-3424-1994) 
Hubungan Kemiringan Saluran Dengan Kecepatan Rata-Rata Aliran

\begin{tabular}{|c|c|}
\hline $\begin{array}{c}\text { Kemiringan } \\
\text { Saluran I } \\
(\%)\end{array}$ & $\begin{array}{c}\text { Kecepatan rata- } \\
\text { rata } \mathrm{v} \\
(\mathrm{m} / \mathrm{s})\end{array}$ \\
\hline$<1$ & 0.4 \\
\hline $1-2$ & 0.6 \\
\hline $2-4$ & 0.9 \\
\hline $4-6$ & 1.2 \\
\hline $6-10$ & 1.5 \\
\hline $10-15$ & 2.4 \\
\hline
\end{tabular}

(Sumber :H.M Halim Hasmar, 2011)

$\mathrm{Q}=\mathrm{F} \cdot \mathrm{Cs} \cdot(\Sigma \mathrm{C} \cdot \mathrm{A}) \cdot \mathrm{I}$

Keterangan :

$\mathrm{Q}=$ Debit Banjir (m3/det)

$\mathrm{F}=$ Faktor konversi, $\mathrm{F}=1 / 360$ untuk $\mathrm{Q}$ dalam $\mathrm{m} 3 / \mathrm{det}$

$\mathrm{F}=100 / 36$ untuk $\mathrm{Q}$ dalam $\mathrm{l} / \mathrm{det}$

$\mathrm{Cs}=$ Koefisien tampungan

$\mathrm{C}=$ Koefisien limpasan

$\mathrm{A}=$ Luas daerah aliran $\left(\mathrm{km}^{2}\right)$.

$\mathrm{I}=$ Intensitas hujan selama waktu konsentrasi (mm/jam).

\section{Sistem Drainase}

Menurut Abdeldayem (2005) drainase adalah suatu proses alami, yangdiadaptasikan manusia untuk tujuan mereka sendiri, mengarahkan air dalam ruangdan waktu dengan memanipulasi ketinggian muka air. Sedangkan menurut Suhardjono (2013) drainase adalah suatu tindakan untuk mengurangi air yang berlebih, baik itu air permukaan maupun air bawah permukaan.Air berlebih yang umumnya berupa genangan disebut dengan banjir.

\section{Sistem Jaringan Drainase}

Sistem jaringan drainase merupakan bagian dari infrastruktur pada suatu kawasan, drainase masuk pada kelompok infrastruktur air pada pengelompokkan infrastruktur wilayah, selain itu ada kelompok jalan, kelompok sarana transportasi, kelompok pengelolaan limbah, kelompok bangunan kota, kelompok energi dan kelompok telekomunikasi (Suripin, 2004).

Air hujan yang jatuh di suatu kawasan perlu dialirkan atau dibuang, caranya dengan pembuatan saluran yang dapat menampung air hujan yang mengalir di permukaan tanah tersebut.Sistem saluran di atas selanjutnya dialirkan ke sistem yang lebih besar.Sistem yang paling kecil juga dihubungkan dengan saluran rumah tangga dan sistem saluran bangunan infrastruktur lainnya, sehingga apabila cukup banyak limbah cair yang berada dalam saluran tersebut perlu diolah (treatment). Seluruh proses tersebut di atas yang disebut dengan sistem drainase (Kodoatie, 2003).

\section{Daerah Aliran Sungai (DAS)}

Daerah Aliran Sungai disingkat DAS ialah suatu kawasan yang dibatasi oleh titiktitik tinggi di mana air yang berasal dari air hujan yang jatuh, terkumpul dalam kawasan tersebut.Guna dari DAS adalah menerima, menyimpan, dan mengalirkan airhujan yang jatuh di atasnya melalui sungai.

Air hujan yang dapat mencapai permukaan tanah, sebagian akan masuk (terserap) ke dalam tanah (infiltrasi), sedangkan air yang tidak terserap ke dalam tanah akan tertampung sementara dalam cekungan-cekungan permukaan tanah (surface detention) untuk kemudian mengalir di atas permukaan tanah ke tempat yang lebih rendah (runoff), untuk selanjutnya masuk ke sungai. Air infiltrasi akan tertahan di dalam tanah oleh gaya kapiler yang selanjutnya akan membentuk kelembaban tanah. Apabila tingkat kelembaban air tanah telah cukup jenuh maka air hujan yang baru masuk ke dalam tanah akan bergerak secara lateral (horizontal) untuk selanjutnya pada tempat tertentu akan keluar lagi ke permukaan tanah (subsurface flow) yang kemudian akan mengalir ke sungai. Batas wilayah DAS diukur dengan cara menghubungkan titik-titik tertinggi di antara wilayah aliran sungai yang satu dengan yang lain.

\section{Daerah - daerah DAS}

1. Hulu sungai, berbukit-bukit dan lerengnya curam sehingga banyak jeram. 
2. Tengah sungai, relatif landai,terdapat meander. Banyak aktivitas penduduk.

3. Hilir sungai, landai dan subur. Banyak areal pertanian.

\section{Macam - Macam DAS}

DAS dibedakan menjadi dua, yakni:

a. DAS gemuk: DAS jenis ini memiliki daya tampung yang besar, adapun sungai yang memiliki DAS seperti ini cenderung mengalami luapan air yang besar apabila terjadinya hujan di daerah hulu.

b. DAS kurus: DAS jenis ini bentuknya sempit, sehingga daya tampungnya pun kecil. Manakala hujan turun di daerah hulu, tidak terjadi luapan air yang tidak terlalu hebat.

\subsubsection{Bentuk - Bentuk DAS}

Bentuk DAS ada tiga jenis, yaitu:

1. Bentuk Bulu Ayam: DAS bentuk bulu ayam memiliki debit banjir sekuensial dan berurutan. Memerlukan waktu yang lebih pendek untuk mencapai mainstream. Memiliki topografi yang lebih curam daripada bentuk lainnya.

2. Bentuk Kipas: DAS berbentuk kipas memiliki debit banjir yang terakumulasi dari berbagai arah sungai dan memiliki waktu yang lebih lama daripada bentuk bulu ayam untuk mencapai mainstream. Memiliki topografi yang relatif landai daripada bulu ayam.

3. Bentuk parallel / Kombinasi: DAS bentuk kombinasi memiliki debit banjir yang terakumulasi dari berbagai arah sungai di bagian hilir. Sedangkan di bagian hulu sekuensial dan berurutan.

\section{Sedimentasi}

$\begin{array}{ccr}\text { Sedimentasi } & \text { adalah } & \text { proses } \\ \text { pengendapan yg dihasilkan } & \text { oleh }\end{array}$ proses erosi yang terbawa oleh suatu aliran pada suatu tempat yg kecepatannya lambat atau berhenti. Sedimentasi (berasal dari bahasa Latin yaitu sedimentum yang berarti "ampas") adalah suatu proses pengendapan / sedimentasi material yang dibawa oleh air, angin, es atau gletser di suatu cekungan. Sedimentasi juga termasuk suatu proses pengendapan material yang diakibatkan oleh air atau udara di bawah pengaruh gravitasi atau gaya sentrifugal. Membentuk bagian bawah lapisan padatan tersuspensi, yang disebut dengan sedimen, sedimen yang tidak dikonsolidasi (batuan lepas).

Sedimentasi dapat dibedakan:

1. Sedimentasiair terjadi di sungai.

2. Sedimentasi angin biasanya disebut sedimentasi aeolis

3. Sedimentasigletser menghasilkandrumlin, moraine,ketles,dan esker.

Berdasarkan Tempat Terjadinya Sedimentasi

1. Sedimentasi sungai

Pengendapan yang terjadi di sungai disebut sedimen fluvial.Hasil pengendapan ini biasanya berupa batu giling, batu geser, pasir, kerikil, dan lumpur yang menutupi dasar sungai.Bahkan endapan sungai ini sangat baik dimanfaatkan untuk bahan bangunan atau pengaspalan jalan.Oleh karena itu tidak sedikit orang yang bermata pencaharian mencari pasir, kerikil, atau batu hasil endapan itu untuk dijual.

2. Sedimentasi Danau

Di danau juga bisa terjadi endapan batuan.Hasil endapan ini biasanya dalam bentuk delta, lapisan batu kerikil, pasir, dan lumpur. Proses pengendapan di danau ini disebut sedimen limnis.

\section{Sedimentasi Darat}

Guguk pasir di pantai berasal dari pasir yang terangkat ke udara pada waktu ombak memecah di pantai landai, lalu ditiup angin laut ke arah darat, sehingga membentuk timbunan pasir yang tinggi.Contohnya, guguk pasir sepanjang pantai Barat Belanda yang menjadi tanggul laut negara itu.Di Indonesia guguk pasir yang menyerupai di Belanda bisa ditemukan di pantai Parang Tritis Yogyakarta.

\section{Sedimentasi Laut}

Sungai yang mengalir dengan membawa berbagai jenis batuan akhirnya bermuara di laut, sehingga di laut terjadi proses pengendapan batuan yang paling besar. 
Hasil pengendapan di laut ini disebut sedimen marin.

\section{METODELOGI PENELITIAN}

Langkah atau metode yang dilakukan dalam mengkaji sistem aliran pada Daerah Aliran Sungai (DAS) Bendung Kuto Palembang yaitu :

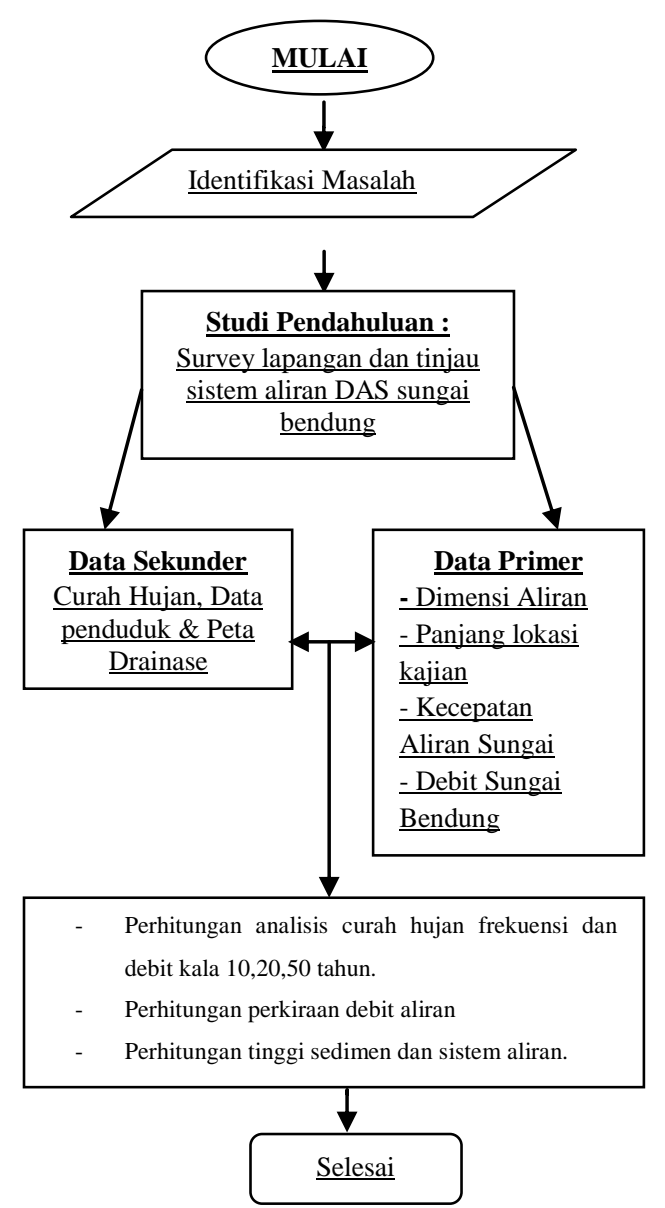

\section{HASIL DAN PEMBAHASAN}

\section{Hasil Analisis Data Curah Hujan}

Curah Hujan Maksimum Rata-rata

\begin{tabular}{|c|c|c|}
\hline NO & Tahun & $\begin{array}{c}\text { Curah Hujan } \\
(\mathrm{mm})\end{array}$ \\
\hline 1 & 2007 & 274,5 \\
\hline 2 & 2008 & 236,6 \\
\hline 3 & 2009 & 211,0 \\
\hline 4 & 2010 & 302,6 \\
\hline 5 & 2011 & 184,5 \\
\hline 6 & 2012 & 216,9 \\
\hline 7 & 2013 & 261,8 \\
\hline 8 & 2014 & 145,3 \\
\hline
\end{tabular}

Kajian Sistem Aliran Pada Daerah Aliran Sungai (DAS) Bendung Kota Palembang (Muhammad Caisar Arfy ${ }^{1)}$, Ishak Yunus ${ }^{2)}$, Mudiono Kasmuri ${ }^{3)}$ )

\begin{tabular}{|c|c|c|}
9 & 2015 & 170,0 \\
\hline 10 & 2016 & 250,1 \\
\hline
\end{tabular}

Sumber : ( BMKG Kenten, 2017)

\section{Curah hujan rancangan}

Untuk menghitung curah hujan rancangan digunakan dengan Metode Gumbel sebagai berikut :

$\mathrm{X}_{\mathrm{T}}=\underline{\bar{X}}+\frac{\left(\mathrm{Y}_{\mathrm{t}}-\mathrm{Y}_{\mathrm{n}}\right)}{\sigma_{\mathrm{n}}} \mathrm{XS}$

\section{Untuk kala ulang 10 tahun,}

dimana :

$\underline{\bar{X}}=225,340 \mathrm{~mm}$

$\mathrm{Yt}=$ 2,2504 lampiran 2.4 Reduced

Variate $(\mathrm{Yt})$

$\mathrm{Yn}=0,4952$ lampiran 2.2 Reduced Mean $(\mathrm{Yn})$

$\underline{\sigma n}=0,9497$ lampiran 2.3 Reduced Standart

$$
\text { Deviation (on) }
$$

$\mathrm{S}=49,283$

$$
\begin{aligned}
& \mathrm{X}_{\mathrm{T}}=\underline{\bar{X}}+\frac{\left(\mathrm{Y}_{\mathrm{t}}-\mathrm{Y}_{\mathrm{n}}\right)}{\sigma \mathrm{n}} \times \mathrm{S} \\
& =225,34+\frac{(2,2504-0,4952)}{0,5497} \times 49,283 \\
& =316,425 \mathrm{~mm}
\end{aligned}
$$

Menghitung curah hujan rancangan dengan kala ulang $\mathrm{T}$ tahun dengan menggunakan Metode Log Person III

$$
\log (\mathrm{Xt})=\underline{\underline{\log X}}+\mathrm{K} \cdot \mathrm{Sd}
$$

dimana :

untuk peroide 10 tahun

$\mathrm{Cs}=-0,5 \rightarrow \mathrm{K}=1,216$ (lampiran 2.5)

$$
\begin{aligned}
\underline{\log \bar{X}} & =2,343 \\
\mathrm{Sd} & =0,099
\end{aligned}
$$

\section{untuk kala ulang 10 tahun,}

$$
\begin{aligned}
\log (\mathrm{Xt}) & =\underline{\overline{\log X}}+(\mathrm{K} \cdot \mathrm{Sd}) \\
= & 2,343+(1,216 \mathrm{x} 0,09964) \\
\log (\mathrm{Xt}) & =2,406407 \\
\mathrm{Xt} & =10^{2,406407} \\
= & 291,119 \mathrm{~mm}
\end{aligned}
$$


Curah hujan rancangan metode Gumbel dan metode Log Pearson

\begin{tabular}{|c|c|c|c|}
\hline \multirow{2}{*}{ No } & \multirow{2}{*}{$\begin{array}{c}\text { Kala } \\
\text { Ulang }\end{array}$} & \multicolumn{2}{|c|}{$\begin{array}{c}\text { Curah Hujan Rancangan } \\
(\mathrm{mm})\end{array}$} \\
\cline { 3 - 4 } & & $\begin{array}{c}\text { Metode } \\
\text { Gumbel }\end{array}$ & $\begin{array}{c}\text { Metode Log } \\
\text { Pearson }\end{array}$ \\
\hline 1 & 5 & 277,505 & 268,039 \\
\hline 2 & 10 & 316,425 & 291,118 \\
\hline 3 & 25 & 365,625 & 315,533 \\
\hline 4 & 50 & 402,125 & 331,108 \\
\hline 5 & 100 & 438,416 & 344,910 \\
\hline
\end{tabular}

(Sumber: Hasil perhitungan,2017)

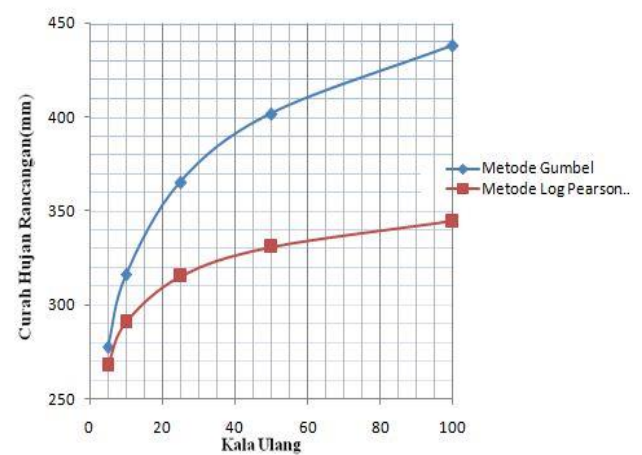

Grafik CurahHujan Rancangan Metode Gumbel dan Log PearsonType III

9 Syarat jenis sebaran

\begin{tabular}{|c|c|c|c|c|}
\hline \multirow{2}{*}{ No } & JenisDistribusi & Syarat & $\begin{array}{c}\text { Hasil } \\
\text { hitungan }\end{array}$ & Kesimpulan \\
\hline \multirow{4}{*}{1} & & $\mathrm{Cs} \leq$ & $\mathrm{Cs}=-$ & \\
& & 1,1396 & 0,126 & Memenuhi \\
& & $\mathrm{Ck} \leq$ & $\mathrm{Ck}=$ & \\
\hline \multirow{3}{*}{2} & & 5,4002 & 3,252 & \\
& \multirow{2}{*}{ Log Person III } & & $\mathrm{Cs}=-$ & \\
& & & 0,126 & Tidak \\
& & $\mathrm{Ck}=$ & memenuhi \\
\hline
\end{tabular}

(Sumber: Hasil perhitungan,2017)

Dari perhitungan analisis frekuensi curah hujan diatas maka didapat yang memenuhi syarat adalah dengan menggunakan metode gumbel. Oleh sebab itu perhitungan intensitas curah hujan menggunakan hasil curah hujan rancangan metode gumbel.

\section{Perhitungan Intensitas curah hujan}

Hitung intensitas hujan rencana dengan periode ulang $5,10,25,50,100$ tahun dengan rumus :

Metode Mononobe

Rumus yang dipakai adalah :

Dimana :
$\mathrm{I}=$ intensitas curah hujan ( $\mathrm{mm} / \mathrm{jam})$

$\mathrm{R}_{24}=$ Curah hujan maksimum (mm)

$\mathrm{t}_{\mathrm{c}}=$ Waktu konsentrasi

Diketahui :

$\mathrm{R}_{24}($ curah hujan kala ulang 10 tahun $)=$

$316,426 \mathrm{~mm}$

tc $=0,066 \mathrm{jam}$

Intensitas curah hujan, untuk titik T1-T2 dapat dihitung dengan menggunakan rumus :
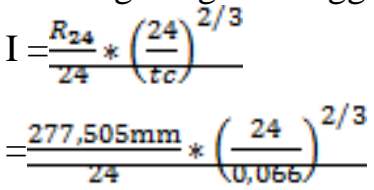

$=671,693 \mathrm{~mm} / \mathrm{jam}$

\section{Perhitungan Debit Rencana}

Untuk menghitung debit rencana diambil contoh titik T1-T2 pada dengan rumus sebagai berikut :

$Q=0,278$. C.I.A

Contoh titik T1-T2

Dimana :

$\mathrm{C}=0,4$ (lampiran tabel 2.6)

$\mathrm{I} \quad=513,537 \mathrm{~mm} / \mathrm{jam}$

$$
\mathrm{A}=0,0244 \mathrm{~km}^{2}
$$$$
Q=0,278 . C . I . A
$$

$=0,278 \times 0,4 \times 513,537 \times 0,024$

$=1,393 \mathrm{~m}^{3} / \mathrm{det}$

Selanjutnyamenghitung populasi penduduk pada tiap Sub daerah tangkapan pada wilayah.

Perhitungan populasi untuk area A1 := $\frac{\text { luas area A1 }}{\text { Luascathmentarea }} \times$ jumlah penduduk cathment area

$$
=\frac{0,024}{0,1507} \times 2647=421,55 \text { jiwa } \simeq 422 \text { jiwa }
$$

\section{Perhitungan debit air kotor}

Perhitungan debit air kotor pada titik T1$\mathrm{T} 2$ atau area A1 debit air kotor diperhitungkan sebagai berikut:

Debit air buangan tiap orang

$=150$ liter/orang/hari

populasi penduduk $=422$ jiwa

$\mathrm{Q}$ air kotor A1 = Debit air buangan tiap orang x populasi Penduduk

$$
=150 \text { liter/orang/hari } \mathrm{x} 422 \text { jiwa }
$$


$=63300$ liter $/$ hari

$=0,00073 \mathrm{~m}^{3} / \mathrm{s}$

\section{Perhitungan Debit Kumulatif}

Debit kumulatif merupakan penjumlahan dari debit limbah atau air hujan $\left(\mathrm{Q}_{\text {limpasan }}\right)$ dan debit air limbah atau air kotor $\left(\mathrm{Q}_{\text {limbah }}\right)$. Perhitungan debit kumulatif pada titik T1$\mathrm{T} 2$ atau area A1sebagai berikut :

$$
\begin{aligned}
\mathrm{Q}_{\text {total }} & =\mathrm{Q}_{\text {limpasan }}+\mathrm{Q}_{\text {limbah }} \\
& =1,683+0,0007 \\
& =1,6837 \mathrm{~m}^{3} / \mathrm{det}
\end{aligned}
$$

\begin{tabular}{|c|c|c|c|c|}
\hline \multirow[t]{2}{*}{ No } & \multirow[t]{2}{*}{$\begin{array}{l}\text { Arah } \\
\text { Aliran }\end{array}$} & $\begin{array}{c}\mathrm{Q} \\
\text { akumulatif }\end{array}$ & $\begin{array}{c}\text { Q air } \\
\text { buang } \\
\text { kumulatif }\end{array}$ & Q gab \\
\hline & & $\left(\mathrm{m}^{3} / \mathrm{s}\right)$ & $\left(\mathrm{m}^{3} / \mathrm{s}\right)$ & $\left(\mathrm{m}^{3} / \mathrm{s}\right)$ \\
\hline 1 & $\mathrm{~T} 1$ - T2 & 1,683 & 0,00073 & 1,68373 \\
\hline 2 & $\mathrm{~T} 3-\mathrm{T} 4$ & 0,713 & 0,00031 & 0,71331 \\
\hline 3 & $\mathrm{~T} 4-\mathrm{T} 6$ & 0,789 & 0,00043 & 0,78943 \\
\hline 4 & $\mathrm{~T} 5-\mathrm{T} 4$ & 2,291 & 0,00098 & 2,29198 \\
\hline 5 & $\mathrm{~T} 2-\mathrm{T} 5$ & 1,965 & 0,00082 & 1,96582 \\
\hline 6 & $\begin{array}{l}\text { T5 - } \\
\text { T11 }\end{array}$ & 3,750 & 0,00158 & 3,75158 \\
\hline 7 & T8 - T9 & 0,089 & 0,00003 & 0,08903 \\
\hline 8 & $\begin{array}{l}\text { T9- } \\
\text { T10 }\end{array}$ & 0,282 & 0,00012 & 0,28212 \\
\hline 9 & $\begin{array}{l}\text { T7 - } \\
\text { T12 }\end{array}$ & 1,158 & 0,00058 & 1,15858 \\
\hline 10 & $\begin{array}{l}\text { T7 - } \\
\text { T13 }\end{array}$ & 1,965 & 0,00135 & 1,96635 \\
\hline 11 & $\begin{array}{l}\text { T13 - } \\
\text { T14 }\end{array}$ & 1,138 & 0,00058 & 1,13858 \\
\hline & & TOTAL & & 15,83051 \\
\hline
\end{tabular}

Tabel Debit Kumulatif

(Sumber: Hasil perhitungan,2017)

\section{Perhitungan pada penampang saluran}

Lebar dasar saluran $(\mathrm{b})=1,2 \mathrm{~m}$

Tinggi basah saluran $(\mathrm{h})=1,2 \mathrm{~m}$

$\mathrm{A}=\mathrm{b} . \mathrm{h} \quad \mathrm{P}=\mathrm{b}+2 \mathrm{~h}$

$$
\begin{gathered}
=1,2 \mathrm{~m} \times 1,2 \mathrm{~m} \\
=1,44 \mathrm{~m}^{2}=1,2+(2 \times 1,2 \mathrm{~m}) \\
\mathrm{R}=\frac{\mathrm{A}}{\mathrm{p}} \\
=\frac{1,44 \mathrm{~m}^{-}}{3,6 \mathrm{~m}} \\
=0,4 \mathrm{~m}
\end{gathered}
$$

Dari Tabel dapatdilihatbahwa perhitunganpadabeberapapenampangsalura $\mathrm{n}$ DAS sungai Bendung Kuto masihmemenuhiatau tidak, maka perlu dihitung debit yang akanmasukkemasing- masingsaluran kemudian dibandingkan dengan kapasitasangkutsaluran.

1. Perhitungan Debit Eksisting :

Penampangsaluran $\mathrm{S}_{1}$

Luaspenampangbasahsaluran

$(\mathrm{A})=1,44 \mathrm{~m}^{2}$

Kelilingbasahsaluran

(P) $\quad=3,6 \mathrm{~m}$

Jari-jarihidrolis

$(\mathrm{R})=0,4 \mathrm{~m}$

Kemiringansaluran

(S) $\quad=0,002$

Koefisienkekasaran Manning untukbeton (n) $=0,015($ tabel 2.10$)$

$$
\begin{aligned}
\mathrm{V}= & \frac{1}{\bar{n}} \cdot \mathrm{R}^{2 / 3} \cdot \mathrm{S}^{1 / 2} \\
= & 1 / 0,015 \times 0,4^{2 / 3} \times 0,002^{1 / 2} \\
& =1,44 \mathrm{~m} \times 1,618 \mathrm{~m}^{2} / \mathrm{det} \\
& =1,618 \mathrm{~m}^{2} / \mathrm{det} \\
& =2,330 \mathrm{~m}^{3} / \mathrm{det}
\end{aligned}
$$

Perbandingan Q Eksisting dan Q Rasional

\begin{tabular}{|c|c|c|c|c|}
\hline $\begin{array}{c}\text { Penampa } \\
\text { ng } \\
\text { saluran }\end{array}$ & $\begin{array}{c}\text { Total Q } \\
\text { Eksisting } \\
(\mathrm{m} 3 / \mathrm{det})\end{array}$ & $\begin{array}{c}\text { Total Q } \\
\text { Rasional } \\
(\mathrm{m} 3 / \mathrm{det})\end{array}$ & $\begin{array}{c}\text { Perbe } \\
\text { daan }\end{array}$ & Keterangan \\
\hline $\mathrm{S} 1$ & 2,330 & 1.683 & 0,647 & Memenuhi \\
\hline $\mathrm{S} 2$ & 2,330 & 1.683 & 0,647 & memenuhi \\
\hline $\mathrm{S} 3$ & 1,432 & 1.683 & - & Tidakmemenuhi \\
\hline $\mathrm{S} 4$ & 1,432 & 1.683 & - & Tidakmemenuhi \\
\hline
\end{tabular}

(Sumber: Hasil survey data lapangan,2017)

Dimensi Sungai Bendung Kuto Palembang

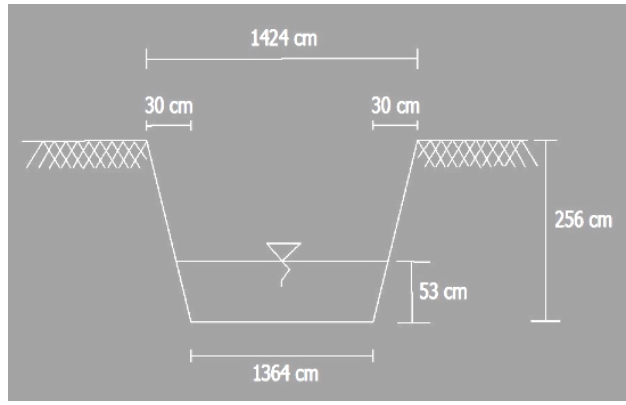

\section{Gambar Penampang Eksisting Sungai Bendung Kuto}

Sumber : Hasil Analisis, 2017 


\section{KESIMPULAN}

Berdasarkan hasil pengamatan langsung di lapangan, maka dapat diambil beberapa kesimpulan, yaitu :

1. Penyebabmelimpahnya air hujan di Daerah Aliran Sungai (DAS) Sungai Bendung Kuto Ilir Timur II Palembang adalah akibat ketidak-mampuan pada beberapa saluran, yaitu saluran dari S3 dan S4 untuk mengalirkan air hujan karena kapasitasnya yang lebih kecil (Q Eksisting $=1,432 \mathrm{~m} 3 / \mathrm{det}$ ) dari debit yang masuk $(\mathrm{Q}$ Rasional $=1,683$ $\mathrm{m} 3 /$ det).

2. Dari hasil analisa curah hujan rancangan metode gumbel dan log person III, yang memenuhi syarat jenis sebaran adalah metode Gumbel dengan nilai $\mathrm{Cs}=-0,5113<1,1396$ (Memenuhi) dan nilai $\mathrm{Ck}=3,252<$ 5,4002 (Memenuhi) .

\section{SARAN}

Adapun saran yang perlu dilakukan dengan tujuan untuk menangani masalah Banjir khususnya di Daerah Aliran Sungai Bendung Kuto Palembang, yaitu :

1. Sebaiknya penelitian kecepatan aliran ini dilakukan di jalur sungai yang lurus, Pengukuran kecepatan aliran dan ketinggian muka air dilakukan secara berulang agar dapat mengurangi faktor kesalahan dan agar mendapatkan hasil yang lebih teliti.

2. Penelitian berikutnya sebaiknya dilakukan dengan bentuk penampang yang berbeda agar dapat dibandingkan dengan hasil penelitian ini.

3. Sebaiknya tiap - tiap sungai dilengkapi oleh jalan inspeksi agar sampah tidak masuk kebadan air 